\title{
O CONCEITO EPICURISTA DE KRITÊRION VINCULADO AO DE ENARGEÍAS E DE KANÔN
}

\author{
Miguel Spinelli* \\ migspinelli@yahoo.com.br
}

RESUMO O presente artigo analisa o conceito epicurista de kritêrion dentro dos limites dos escritos remanescentes de Epicuro. Ele busca sondar o que efetivamente Epicuro disse ou quis dizer com esse termo. Dado que o conceito não comparece sozinho, mas vinculado ao de enargeías, kanôn $e$ krísis, então este estudo se ocupa também em analisar essa vinculação.

Palavras-chave Epicuro, kritêrion, enargeías, kanôn, krísis.

ABSTRACT This article analyses the concept of Epicurean kritêrion within the limits of the remaining writings of Epicurus. It tries to investigate what Epicurus actually said or aimed to say by this term. Since this concept does not appear alone, but linked to the notion of enargeías, kanôn and krísis, this study also deals with their interrelations.

Keywords Epicurus, kritêrion, enargeías, kanôn, krísis.

\section{O uso e significado de kritêrion nos escritos remanescentes de Epicuro}

O termo critério comparece seis vezes nos escritos remanescentes de Epicuro: quatro na Carta a Heródoto, uma na Carta a Pítocles e uma nas Máximas Principais, na qual Epicuro se vale também da expressão krísis, a 
fim de expressar um juízo nos moldes de um questionamento de verdade ou de falsidade. O termo cânone consta uma única vez, na Carta a Meneceu ${ }^{1}$.

Nas quatro vezes que o termo critério é usado na Carta a Heródoto, o significado que ele comporta não condiz com o que habitualmente concebemos por critério, mas tende a condizer. Hoje concebemos por critério uma deliberação (princípio ou regra) racionalmente elaborada e posta como base para instruir o discernimento ou exercitar o juízo na tarefa da ciência. Critério, para Epicuro, em seu primordial sentido, diz respeito a uma imposição (ao que ele denomina de epibolê) natural ou involuntária, de modo que em si o conceito não aloja a idéia de um modelo normatizado racionalmente. Por esse ponto de vista, quando ele diz critério, refere-se, antes de tudo, a um vigor natural que se sobrepõe à apreciação ou juízo: vigor mediante o qual não somos levados primordialmente a distinguir o certo do errado (e vice-versa), mas a adotar o certo ou o errado como se fosse o verdadeiro. Está aí, pois, a grande dificuldade que Epicuro tomou para si, e que, inclusive, propôs aos seus discípulos que o ajudassem a resolver:

"Tudo o que aqui foi dito [diz ele no final da Carta a], Pítocles, procure rememorar. Verás como te livrarás de muitos mitos, e como poderás identificar umas quantas outras do mesmo gênero. Mas, sobretudo, te apliques tu mesmo a teorizar a respeito dos princípios, do infinito, e de coisas semelhantes, dos critérios (te kritêríon), e também das impulsões e de tudo aquilo em vista do qual nós nos dedicamos a investigar"'

Primeiro: do fato de Epicuro não atribuir apenas para si a tarefa da execução de seu próprio projeto filosófico, mostra, por um lado (e mais uma vez), o caráter propedêutico de sua doutrina; por outro, denuncia como a tarefa de conhecer a si mesmo (de conhecer a natureza humana) é coletiva, e requer um dedicado empenho subjetivo, sendo que o mesmo vale quanto à dedicação em favor da verdade ou da busca por ciência; segundo: dois fatores contribuíram para que Epicuro desse ao termo critério uma conotação distinta da habitual: $1^{\circ}$ ) o objetivo maior (o télos) de sua doutrina: a busca por serenidade e paz; $2^{\circ}$ ) o fundamento primeiro (o prôton archê) da doutrina: o reconhecimento da natureza mínima que podemos (e, por suposto, devemos) nos inteirar a respeito das coisas, e, de modo prioritário, a respeito de nós mesmos. Juntando estes dois objetivos - a busca por serenidade e o tornar-se ciente de nossa

1 Respectivamente: 38, 51, 52 e 82; 116; XXIV; 129 - Fontes: EPICURE. Lettres et Maximes. Texte établie par Marcel CONCHE. Paris: PUF, 1987; La lettre d'Épicure [à Hérodote]. Introduction, texte et commentaire avec glossaire, index grammatical et index des mots grecs par Jean BOLLACK, Mayotte BOLLACK, \& Heinz WISMANN. Paris: Éditions de Minuit, 1971.

2 Carta a Pítocles, 116 
natureza humana - resultou para Epicuro a necessidade de reconhecer, e não de impor critérios. Daí por que, primordialmente, o que entrou em questão foi a busca por critérios, ou seja, aprender a reconhecer tudo o que a natureza em nós dispõe e que intervém no exercício do discernimento ou do juízo.

Por duas vezes na Carta a Heródoto, Epicuro vincula o termo critério ao de evidência (tà enargeía), expressão do que, em nossa mente, se sobrepõe (se projeta, no sentido da epibolê) a partir das phantasíai sorvidas do sensível ${ }^{3}$. Foi, com efeito, Cícero quem traduziu a enargeía dos gregos por evidência, e preferiu evidentia a illustratio: “... nada há de mais claro (disse ele) que a enargeía, como dizem os gregos. Entre nós a denominamos de perspicuidade (perspicuitas) ou então de evidência..."4. Foi, pois, a propriedade do "ser claro - esset clarius" que levou Cícero a especificar a enargeía quer nos termos de uma perspicuidade (do que se pode ver nitidamente, de modo claro, manifesto), quer, propriamente, no de evidência. Foi, além disso, em vista desse mesmo "ser claro" que Quintiliano veiculou como sendo de Cícero a noção de ilustração (de illustratio) como sinônimo de evidência ${ }^{5}$. Quintiliano, por sua vez, deu ao conceito de illustratio uma conotação essencialmente retórica: no sentido de que seria função da atividade oratória reproduzir nos ouvintes (claro que pela via do discurso e na forma de um artifício) um efeito análogo ao da enargeía produzido na percepção.

Epicuro recriminaria Quintiliano por desrespeito à soberania do humano. Sob nenhum aspecto a sua doutrina comporta qualquer artifício invasivo na forma de uma doçura ou sedução verbal, enquanto malandragem retórica, destinada a cativar, e, portanto, a suplantar a mente e a vontade do outro. A enargeía tem nele um sentido apenas epistêmico: o de evidência restrita à conotação de kritêrion, ou seja, de um modo humano natural de criar para si armadilhas a partir das "projeções sensíveis (dadas no recinto) da mente". Perante as coisas, perante qualquer fenômeno, o sujeito senciente tem sempre

3 "tà kritêria... tà katà tàs energeías - os critérios alçados (a essa condição) pelas forças" (Carta a Heródoto, 52); "tôn kritêríôn enargeía - a evidência relativa a cada critério" (Carta a Heródoto, 82).

4 “... quod nihil esset clarius enargeia, ut Graeci: percipuitatem aut evidentiam nos...” (CíCERO. Acadêmica, II, 17 - Academica. The text revised and explained by J. S. Reid. Hildesheim: Olms, 1984). STRIKER, G.. "Kritêrion tês alêtheias". Nachriten der Akademie der Wissenschaften in Göttingen, Phil-hist.Klasse, 1974, pp.51-110; LONG, Anthony Arthur. Hellenistic philosophy: Stoics, Epicureans, Sceptics. 2 $2^{\mathrm{a}}$ ed.. Berkeley and Los Angeles: University of California Press, 1986; LÉVY, Carlos \& PERNOT, Laurent (Éds.). Dire l'evidence. Philosophie et rhétorique antiques. Textes réunis. Paris: L'Harmattan, 1997, p.10ss; nesse mesmo volume de Lévy-Pernot há um capítulo "Les évidences dans la philosophie hellénistique", de W. GÖLLER, que trata da mesma questão, p.131ss.

5 “... enargeia, quae a Cicerone illustratio et evidentia nominatur..." (QUINTILIANO. Regulamentação Oratória, VI, 2, 32 - Institutio Oratoria. Translated by H.E. Butler. Cambridge, MA: Harvard University Press, Loeb classical library, 1996).

6 phantastikên epibolên tês dianoías (Máximas principais, 147, XXIX). 
a sua mente invadida por um algo vívido, iluminante, reluzente (que ele chama argós), que o cativa e o afeta. Toda percepção sensível promove na mente um algo que reluz, em si dotado de uma intensidade (da enargeía dita por ele) específica, e, sobretudo, de uma potência (energeía) provocativa. Trata-se de um movimento e de uma ação naturais, em vista do que o sujeito senciente deriva para si certezas manifestas: assentimentos que não comportam dúvidas, quer quanto à sua verdade quer quanto à sua falsidade.

$\mathrm{Na}$ medida em que as enargeías (as evidências) são por Epicuro concebidas como dotadas de energeías (de forças, vigores), então faz sentido manter a fórmula original, constante na Carta a Heródoto. Foi, aliás, Gassendi quem alterou a fórmula: de tàs energeías (de as potências ou forças) para tàs enargeías (para as evidências ou clarividências). Sem maiores justificativas, Gassendi pôs um " $\alpha$ " (um alfa) no lugar de " $\varepsilon$ " (de epsílon), e o resultado ficou assim: antes de afirmar que os critérios são alçados à condição de critério pelas forças (como consta na fórmula original), assim se dá pelas evidências inerentes ao percepto sensível". Essa mudança (de um "alfa" para um "epsílon", talvez fruto de um descuido ingrato), a bem da verdade pouco interferiu no texto da Carta Epicuro. Mesmo que bastante significativa, ela apenas pôs à mostra, não a rigor uma equivalência, mas o quanto um conceito se explica pelo outro. Tanto é verdade, que, na mesma Carta (§ 48), Epicuro se valeu de uma outra vez do termo energeía, justo para expressar as forças agentes (em nós) do percepto sensível, ou, como ele denominou, as forças da phantasia.

Ora, é a evidência, do ponto de vista de Epicuro, que define o critério. Melhor dizendo: é a força da evidência que dá às phantasíai da mente a condição de critério, e, assim, juntos, enargeía, energeía e kritêrîon compõem uma mesma questão: aquela segundo a qual existem forças naturais que se impõem na condição de critério, e que agem sobre nós, mediante uma evidência específica. Kritêríôn, pois (não dá para negar), tem em Epicuro uma função paradigmática - encerra um paradigma, modelo ou padrão - no contexto fragmentário de sua doutrina ${ }^{8}$. Trata-se, com efeito, de uma imposição, mas

7 de tà kritêria anaírêtai tà katà tàs energeías por tà kritêria anaírêtai tà katà tàs enargeías (Carta a Heródoto, 52). Na tradução de Mário Kury comparece evidência... DIÓGENES LAÉRTIO. Vidas e Doutrinas dos Filósofos Ilustres. Trad. de Mário da Gama Kury, Basília: UnB, 1988.

8 Encontramos em Adriana Zangara algumas observações que concordam com o esse ponto de vista: "Em Epicuro, o uso predominante da noção (Zangara se refere à energeía) repousa principalmente sobre uma analogia entre kritêrion e kanôn. Feito um kanôn, uma regra que é paradigmaticamente reta, o kritêrion fornece verdades imediatas que têm uma função paradigmática - Chez Épicure, l'usage prédominant de la notion repose pincipalement sur une analogie entre kritêrion et kanôn. À l'instar d'un kanôn, une règle qui est paradigmatiquement droite, le kritêrion fournit des vérités immediates qui ont une fonction paradigmatique" (ZANGARA, A.. Voir l'histoire. Théories anciennes du récit historique. Paris: Vrin, 2007, 
por força da natureza, na medida em que algo se manifesta à mente de modo vívido, e, por esse apresentar-se, vem a se constituir em um testemunho crível, valioso. Daí que kritêriôn diz respeito ao que vem a se impor como um saber ou verdade (a título de uma dóxa) dada de imediato à mente, pela via do sensível: verdade que o indivíduo senciente cultiva como uma certeza, e da qual as phantasiai (as imagens ou representações mentais) resultam para ele em testemunhos (martyriai) confiáveis.

Que as evidências agem com força em nós, isso é fato. Também não podemos negar que elas, por esse agir ou operar (érgon), nos afetam, e que, por esse afetar, nos transformam em indivíduos opinativos: temos logo a necessidade de dizer algo, quer no sentido de perguntar para o outro ou confabular com o indivíduo que de nós está mais próximo, quer no de propalar afirmações ou dar explicações para quem quer seja. As evidências circunstanciam de tal modo a natureza humana do indivíduo particular, que tanto podem ser causa da verdade, quanto induzir a erro, sobretudo facilitar que em nós se instale a inquietação e o medo.

Ocorre que as evidências (quaisquer que sejam) nos levam sempre a formular opiniões, e, por suposto, a crer nelas ou a desconfiar delas. São, com efeito, tais evidências (em dependência de sua força ou potência impressiva) que dão ao sujeito senciente tanto o critério de certeza (ou de verdade) quanto o de falsidade. São, a bem da verdade, níveis ou instâncias de evidências que o sujeito senciente toma como critério autenticador de suas opiniões - isso, bem entendido, antes do ajuizamento racional, próprio da instância da ciência: do estudo (do logos verdadeiro ${ }^{9 *}$ a respeito) da natureza $<$ da physiologías $>$, ao qual, segundo Epicuro, cabe ajuizar a força "da causa principal" enquanto evidência <tôn kyriôtátôn aitían $>^{10}$; depois, na medida em que a razão (mais precisamente aquela que busca dissipar a intranquilidade e o medo) põe o conflito (o contencioso, a diakrísis), no momento em que ela pede por certificação, então as opiniões só encontram duas possibilidades: ou serem verdadeiras ou serem falsas.

O processo dessa certificação, Epicuro estipula-o nos seguintes termos: as opiniões "verdadeiras são as confirmadas ou não contraditadas pelas evidências, as falsas são as contraditadas ou não confirmadas pela evidência"11.

p.237). Ela dedicou toda a quarta parte sobre o estudo da enargeía: “Quatrième Partie: L'Enargeia e la Force", p.229ss.

9 * logos verdadeiro, porque um logos falso não constitui uma investigação

10 Carta a Heródoto, 78. Na mesma Carta a Heródoto, 35 os kyriôtata alude a um domínio enquanto fundamentos referentes à investigação sobre a natureza (perì phýseôs theorías).

11 SEXTO EMPÍRICO. Contra os matemáticos, VII, 211 
Quer dizer: se as evidências confirmam e não contradizem as opiniões, ocorre então que as opiniões são verdadeiras, e, as evidências, critérios de verdade (fundamentos <aitiai $>$ da ciência); se elas, ao contrário, não testemunham (ouk epimartyrêsis) em favor das opiniões, se, inclusive, fazem as vezes do antitestemunho (antimartyrêsis), então as opiniões são falsas, e, as evidências, critérios (ou seja, testemunhos certificadores) da falsidade.

Epicuro quando disse que "as sensações são destituídas de razão $<$ aísthêsis álogós $>$ "12, que elas não comportam um julgamento formulado por elas mesmas (afinal, são pura receptividade), com isso retirou das evidências qualquer suposição de que elas em si mesmas pudessem ser verdadeiras ou falsas. Em vista disso, ele concluiu que a verdade e a falsidade não estão nas evidências, mas nas opiniões. Por princípio, segundo ele, as evidências são sempre verdadeiras, enquanto que as opiniões (no confronto das evidências) são ou falsas ou verdadeiras. Na medida em que algum fenômeno se evidência (se mostra ou se manifesta) para nós na natureza, é uma verdadeira manifestação, no entanto, não é em si mesma nem benéfica nem maléfica (boa ou ruim); são as opiniões, que a respeito delas formulamos, que podem ou não ser caracterizadas desse modo.

Daí porque o conhecimento certo, como posto acima - conhecimento, segundo Epicuro, que é promotor de uma natureza humana feliz (makaría phýsei) - está na investigação das causas predominantes (tôn kyriôtátôn aitían $^{13}$ ) quer dos fenômenos quer das evidências, quer ainda dos elementos perceptíveis. Prover aquele conhecimento e investigar aquelas causas, eis a função (a ação ou érgon) primordial da physiologías ${ }^{14}$. E mais (recomenda Epicuro ${ }^{15}$ ): relativo a tais causas predominantes não devemos exagerar na pluralidade, tendo em mente que não cabe, na ciência, o princípio de contradição, isto é, que algo seja ao mesmo tempo assim e não-assim ou que a respeito desse algo, simultaneamente, afirmemos ou neguemos propriedades

12 DIÓGENES LAÉRCIO. Vidas e doutrinas dos filósofos ilustres, X, 32. Cf. também SEXTO EMPÍRICO. Contra os matemáticos, VII, 211 - Adversus Mathematicos. vols. 2-4. Edited by R.G. Bury. Cambridge: MA/ London: Harvard University Press/ W.Heinemann Ltd. (The Loeb Classical Library), 1971.

13 Festugière traduziu tôn kyriôtátôn aitían por "a causa das realidades essenciais - la cause des réalités essentielles" (FESTUGIĖRE, A.-J.. Epicure e ses dieux, p.110); Bollack por "regras capitais - dès règles capitales" (BOLLACK, Jean, et alii. La lettre d'Epicure, p.115); Marcel Conche por "a causa dos fenômenos dominantes - la cause des phénomènes dominantes" (CONCHE, M.. Lettres et Maximes, p.123); Gama Kury, por "causa dos elementos principais"... Oras, as traduções de Festugière e de Bollack são improváveis; as de Conche e de Kury, plausíveis, sendo que ainda acrescentríamos (no rol das kyriôtata) as evidências, traduzindo tôn kyriôtátôn aitían por "a causa das evidências principais" - evidências que confirmam e que não contradizem a verdade, ou vive-versa, evidências que invalidam as ponições, e, se invalidam, é porque as opiniões são falsas.

14 Carta a Heródoto, 78; sobre a questão da explicação única veja também Carta a Pítocles, 97.

15 Tradução livre do da frase "éti te ou tò pleonachôs... hê tárachon mêthén" (Carta a Heródoto, 78). 
contraditórias. Quer dizer: a pluralidade de explicações é própria da física, porém, não lhe é próprio admitir mais de uma causa para cada explicação, e, ademais, cada causa, tem que confirmar ou então testemunhar em favor da explicação (em causa), a fim de que seja verdadeira. Essa explicação plural junto ao cuidado de testificar mediante causas únicas é própria da natureza humana; porque a explicação única, aquela que não pressupõe o contencioso e a perturbação (a diákrisis hê tárachês), essa é própria de uma natureza imortal e feliz (aphtártô kaì makaría phýsei), ou seja, de um Deus.

Por certo, o postulado da explicação única adotado por Epicuro não se restringe às razões que supôs Bignone: a) que Epicuro se valeu do postulado como que de uma necessidade estratégica no sentido de manter o discípulo dentro da doutrina. Nas palavras de Bignone: Epicuro recorreu à explicação única "para evitar que o discípulo fosse levado a dar crédito às explicações dos fenômenos astronômicos e meteorológicos formuladas pelos adversários". Aqui é preciso relevar que a questão fundamental do epicurismo não está em "dar crédito (ou não) a explicações de adversários", e, sim, em "dar crédito a explicações que merecem ou não crédito". Não importa se uma explicação é de um espicurista ou de um não epicurista, o que importa é a validade ou veracidade (por suposto metodológica) intrínseca à explicação. Daí por que o epicurismo é avalista de uma canônica (de um certo padrão normativo, metodológico) e não de uma mera ortodoxia que tivesse por finalidade isolar o epicurismo no confronto de outras doutrinas (alheias ao epicurismo)... Quanto à segunda observação de Bignone, ela também é problemática, sobretudo contraditória, na medida em que supõe o postulado da explicação única como decorrente de uma carência técnica no sentido de instrumentar Epicuro (em relação a fenômenos distantes) na busca de uma causa única para fenômenos múltiplos: "não podendo submeter (isto é o que diz Bignone) os fenômenos astronômicos e meteorológicos a uma observação tal que pudesse individuar a causa, dado o distanciamento em relação a nós, era perigoso aceitar, sobre eles (sobre tais fenômenos), uma explicação única"16. Ora, o postulado gnosiológico de Epicuro é suficientemente claro: para fenômenos múltiplos, causas múltiplas - sendo que o contrário também deve ser considerado, ou

16 Foram estas, efetivamente, as palavras de Bignone (supracitadas com alguma liberdade): “... per evitare che egli potesse credere alle spiegazioni dei fenomeni astronomici e meteorologici date dagli avversarii, raccoglieva tutte quelle che erano possibili, in conformità con la propria dottrina, dichiarando che, non potendosi sottoporre i fenomeni astronomici e meteorologici ad un'osservazione tale che potesse individuarne le cause, per la lontananza rispetto a noi, era pericoloso accettare di essi una spiegazione sola" (BIGNONE E.. L'Aristotele perduto e la formazione filosofica di Epicuro. Firenze: La Nuova Italia, 1973, p.307). 
seja, para causas múltiplas, fenômenos múltiplos! A unificação do múltiplo (pelo que observamos em Epicuro) é sempre contenciosa, temerária, e pode não fazer justiça ao universo (ao um) da totalidade.

\section{Dianoías, ennoíais e a krísis enquanto correlato de kritêrion}

Ainda na Carta a Herótodo, Epicuro, por duas vezes, contrapõe o que denomina de dianoías (a reflexão ou discernimento) ao que se refere como "outros critérios" $"$. A dianoías devemos entendê-la como um pensamento em exercício, enquanto tal um noûs (um pensamento) duplo; duplo, porque não é possível refletir com apenas um pensamento (só e isolado), sem se contrapor a outros, a um ou mais pensamentos. Do mesmo modo seria impossível discernir, exatamente porque o discernimento requer a ambivalência, o conflito das opiniões; conflito que, por sua vez, leva a uma resolução, decisão e escolha deliberada. Sem essa condição, a da ambivalência ou do conflito, a reflexão não prospera e a possibilidade do discernimento (do exercício do juízo) se torna inviável.

Pelo contraposto entre a dinanoías (o discernimento reflexivo) e os "outros critérios", Epicuro deixa verbalmente explícito, primeiro, que o discernir é um critério, e o primordial; segundo, que, além do discernimento (da dianoía), existem outros critérios que nos são conaturais, e que nos condicionam. Pelo fato de sermos racionais - esta é a principal questão - não deixamos nunca de ser naturais, e, na medida em que o somos, temos em nós, ingênito, um modo próprio de ser que nos dispõe (que nos condiciona), e, que, por suposto, cabe a nós averiguar qual efetivamente é essa disposição.

Dessa tarefa, o primeiro pressuposto está na constatação de que, por natureza, não nos é dada a ciência de nós mesmos, mas apenas a capacidade de provê-la; além disso, não há qualquer regra ou lei inerente à nossa natureza que, no decorrer do tempo, nos torna melhores, de modo que cabe a nós prover essa melhoria ou qualificação. Uma coisa, todavia, é certa, não podemos nos auto-conhecer (saber de nossas disposições ou modo natural de ser), e, tampouco, nos qualificar em nossa natureza, desvinculando-nos de nossa própria natureza. Daí o grande desafio humano: primeiro, saber quem somos, ou seja, conhecer a nós mesmos ou a nossa própria natureza; segundo, ser melhores, isto é, qualificar a nós mesmos sem desqualificar a nossa própria natureza: prover melhorias sem humanamente nos desarranjar, elevar-nos (a 
partir de nossos limites) sem nos subjugar à possibilidades que não são nossas, acrescentar sem excluir ${ }^{18}$.

Na mesma proporção em que Epicuro é o filósofo da sensibilidade, também o é do discernimento. O discernimento, no contexto canônico-propedêutico de sua doutrina, é tido como tão necessário quanto a moderação. A condição de felicidade, por exemplo, de quem tem muito, bem mais do que precisa, é contentar-se com o pouco de que carece. Mesmo aquele que é muito rico carece apenas de um bom bife, não tem a necessidade acrescida de comer o boi inteiro! Na medida em que não discernimos, que não usamos a nossa potência reflexiva (uma atitude nada incomum entre os homens) ficamos restritos a critérios naturais, sobretudo deixamos nos levar, por força do aprazível, pelos caminhos do excesso. Se não ativamos em nós a capacidade de discernir (capacidade concebida por Epicuro como um movimento <kínesis $>$ que opera dentro de nós), nos tornamos reféns do movimento natural (operante em nós) das impulsões ou das afecções sensíveis. Epicuro descreve esse movimento assim: "se não há validação (recepção) ou se há invalidação (rejeição) então nasce o falso; se há validação (recepção) ou se há não-invalidação (nãorejeição), nasce a verdade"'19. Um logos falso, cabe lembrar, não é capaz de constituir ou compor uma investigação; se o logos é falso não há, por suposto, evidência capaz de confirmá-lo [afinal, não existem evidências, fenômenos ou elementos falsos relativos às coisas]; não havendo, pois, uma evidência verdadeira que confirme uma opinião falsa, resta então a impossibilidade de se encontrar uma evidência ou fenômeno que confirme a falsidade de uma opinião. A falsidade aguarda apenas por uma condição: ser invalidada. A validação é uma condição própria da verdade.

Epicuro reconhece um intercâmbio entre a coisa e o sujeito que conhece, e, ao mesmo tempo, indica um procedimento a adotar. Nesse intercâmbio, os

18 "Não convém jamais humilhar e rebaixar a nossa natureza, como se ela nada detivesse de forte, de permanente, de superior à fortuna <tên týchên>..." (PLUTARCO. Sobre a tranquilidade da alma (Perì euthymías), 17, 475 D - Fonte: PLUTARQUE. Oeuvres Morales. Tome VII2. Traités 27-36. Texte établi et traduit par Jean Dumontier, avec la collaboration de Jean Defradas. Paris: Les Belles Lettres, 1975).

19 Carta a Heródoto, 51. Os termos entre parênteses estão aí para efeito de um melhor entendimento; na dúvida, entre qual alternativa de tradução, optamos por deixar os dois. As fórmulas gregas são, respectivamente: mê epimartyrêthê hê antimartyrethê, tò pseudos guínetai - eàn dè epimartyrêthê hê mê antimartyrethê, tò alêthés. Epicuro acentua um intercâmbio entre a coisa e o sujeito que conhece, e, ao mesmo tempo, indica um procedimento a adotar. Nesse intercâmbio, os órgãos sensíveis exercem a função de testemunha (marturía). Enquanto testemunhas os sentidos dizem ou depõem algo, mas requer daquele que ouve uma presença atenciosa, uma disposição, porque, diante do depoimento da testemunha, é necessário um posicionamento. Sem ele (sem exercício da inteligência ou do juízo), o depoimento diz o que bem quer: há inevitavelmente uma recepção, um aprendizado, e o humano colhe em confiança (DUMONT, J.-P.. "Confirmation et disconfirmation". In: BARNES, J., BRUNSCHWIG, J. et alii (Eds.). Science and Speculation in Hellenistic Philosophy and Practice. Cambridge: University Press, 1982, pp.273-303). 
órgãos sensíveis exercem a função de testemunhas (martyría), e, enquanto testemunhas, dizem ou depõem algo a favor ou contra, e isso independe de uma presença (de uma disposição) racional atenciosa ou não. Há, inevitavelmente, um depoimento e uma recepção, e, portanto, um aprendizado: um acolhimento em confiança, e que, enquanto tal, exerce a função ou se impõe como critério (como um modelo ou referencial a serviço da krísis - do pôr algo em crise ou sob desconfiança). A krísis indica (mais que uma indecisão) a necessidade de se tomar uma decisão, postura que é decorrente de uma arbitragem (seja ela plenamente racional ou não), e denota também uma escolha (não necessariamente deliberada). É, com efeito, em dependência do nível de racionalidade (ou seja, da educação racional) do sujeito senciente, que as evidências projetadas à mente tomam o seu próprio destino: adquirem sentido mediante o universo das palavras ou do discurso proferido (pelo sujeito), e da capacidade deliberativa ou de ajuizamento que ele pode ter.

Quanto ao termo krísis, ele consta apenas uma vez nos fragmentos da doutrina de Epicuro. Ele comparece justo nas Máximas principais ${ }^{20}$, e se apresenta como um correlato de kritêrion. Ali, a krísis designa um julgamento, mas não uma apreciação ou contencioso dirigido ao ato da receptividade sensível, e sim às opiniões já formadas a partir de noções (ennoíais) derivadas do projetar-se à mente de imagens (phantastikên epibolên) sorvidas no sensível. Uma sensação, no dizer de Epicuro, sempre promove em nós certa opinião, que, por sua vez, carece de discernimento, ou seja, saber o a partir do que (de que evidências, fenômenos, perceptos, a partir dos quais) ela foi formada, qual a impulsão e a imagem que a partir dela tomou conta da mente, enfim, quais as consequências que ela em nós (humanos subjetivamente considerados) promove. Ora, negar ou simplesmente rejeitar em nós uma sensação qualquer, corresponde a descartar tudo isso; trata-se de uma atitude vã, que desestabiliza em nós a capacidade de ter sensações e de ter opiniões (ou seja, de tomar decisões, visto que uma opinião comporta orientação $\left.{ }^{21}\right)$. Cabe também destacar que uma nova opinião sempre se ajusta à ordem (instalada na mente) das opiniões anteriores. Daí por que velhas opiniões se antecipam (no sentido dos prólêpsis) a novas opiniões, de tal modo que, por essa mescla, a mente se vê levada a reconstituir uma nova ordem, e, sobre ela, assentar (como que numa continuidade) o sossego e a paz na alma ${ }^{22}$.

20 147, XXIV.

21 Pensamos aqui no conceito epicureo de kenêrn dóxan em geral traduzido por opinião vazia, mas que também pode significar apenas carente de opinião.

22 A mente humana carece necessariamente de ordem. Talvez seja por isso que a razão humana é, por sua natureza, ordenadora. O confuso não combina com a razão humana, antes, pede por ordem, sobre 
São, com efeito, nas opiniões (sobrepostas como explicações das evidências) que, segundo Epicuro, residem a falsidade e o erro ${ }^{23}$. São, todavia, nas opiniões, e não nas evidências, que se originam as principais inquietudes da alma humana ${ }^{24}$. Renunciar as evidências, e com elas o sensível, além de um ato totalmente falho, corresponderia a recusar a nós mesmos, de modo particular as circunstâncias naturais que nos levam (nos movem) a executar a nós próprios como homens. $\mathrm{O}$ mesmo também se aplica às nossas impulsões naturais, dadas em nós para serem regradas e não extirpadas. Com tal atitude pomos a perder todo o vigor natural que nos estimula e ativa (na moral, para a virtude, na ciência, para a busca do saber), a ponto de relegarmos ou extirpar (em nós) nossos próprios critérios naturais. São, ademais, desses critérios que escoa a fonte do exercício do juízo: a avaliação do que, para nós, é correto ou incorreto, a ser acolhido ou a ser rejeitado. Deles também deriva a senda da verdade, porquanto ela nasça dentro (sob a marca de nossa realidade) e não fora de nós (sob a marca de verdades alheias ou que não são nossas, condizentes com nossos limites e possibilidades). Nesse nível, o das evidências, o que naturalmente não validamos, e que, portanto, rejeitamos, assim o fazemos, porque é falso (tò pseudos), ou seja, porque é contrário à nossa natureza; já, o oposto, se validamos ou espontaneamente acatamos, é porque é verdadeiro (tò alêthés), ou seja, condiz com a nossa realidade humana natural de ser.

A função das evidências é apaziguar a alma, mas, para isso, se faz necessário, investigá-las: executar sobre elas o discernimento. Elas são sempre verdadeiras, mas não descartam a investigação. Afinal, carecemos de algum discernimento a fim de nos apropriarmos de sua verdade ${ }^{25}$. Daí que investigar

a qual assentamos a serenidade e a paz. Independentemente de sua verdade ou de sua falsidade, o ordenamento da mente é condição sine qua non de paz duradoura. Na medida, porém, em que o reconhecemos como falso, a mente acorre em arranjá-lo... A mente humana, consciente de si, não combina nem com a desordem e nem com a falsidade. Toda a dificuldade, entretanto, está na educação da razão; mas educar não significa apenas dar um modelo em referência ao qual a razão estabelece o que é falso e o que é verdadeiro. A razão que apenas acolhe modelos fica carente de exercício; a não se que se exercita a partir dos modelos, o que, por princípio, significa colocá-los em crise. Trata-se, com efeito, de um movimento necessário: aquele sem o qual a razão não toma consciência de si.

23 Carta a Heródoto, 50

24 hóti tárachos ho kyriôtatos taîs anthrôpínais psychais gínetai (Carta a Heródoto, 81).

25 O conceito baconiano de "interpretação da Natureza", em vista do que concebeu o que denominou de nova indução, se deu na história da filosofia como uma intensificação da perspectiva epicurista. A prática do que ele denominou de "boa e legítima indução" requeria "exame e prova (examinatio et probatio), a fim de efetivamente verificar se o axioma constituído está adequado e dentro dos limites dos fatos particulares dos quais foi extraído". É dessa exigência que Bacon, ao modo de um epicurista, deriva a tarefa do inquiridor de "analisar a experiência", de operar com fatos e não com abstrações, de lidar com realidades concretas (in materia), e não com formas puras abstratas, destituídas de percepção ou de realidade. Ao inquiridor cabe induzir o que é (mesmo à revelia de seus preconceitos), e não o que supõe ou gostaria que fosse. Por isso, em última instância, cabe a quem investiga jamais se abstrair da experiência (das evidências), porque ela é o lugar e fonte da indução, e, sobretudo, porque sem ela o intelecto resta 
significa acolher (de um modo racional) as evidências, exercitar sobre elas a nossa capacidade humana de ver o verdadeiro; se não fosse assim, a verdade, para nós, seria pura espontaneidade, e, portanto, ela nos seria dada por natureza, sem requerer empenho. É por esse empenho que nos qualificamos como humanos, e que, por suposto, edificamos a ciência. Nesse caso (e aqui está a grande questão enfrentada por Epicuro), mais do que nas opiniões, é no modo irracional como o indivíduo humano dispõe a si mesmo ou de si mesmo perante o que é evidente que está a fonte das turbações que se instalam na alma ${ }^{26}$. Trata-se, todavia, de conflitos sanáveis: basta dedicar-se ao estudo e à investigação que eles se vão. Aliás, na atividade de estudo assim como na do fazer ciência, o método é oposto ao do vício: o principal método contra o vício consiste em evitar o começo; já o principal método em favor do estudo consiste em começar (vencer a indolência, a preguiça, etc.)...

Sobre a relação entre saber e tranquilidade de alma, eis, nesse sentido, o que escreveu Epicuro a Pítocles: "Se, com efeito, entramos em conflito com as evidências <enargêmasin>, jamais poderemos alcançar uma genuína ataraxia" 27 . Bem por isso que uma das condições para a ataraxia (termo que Lucrécio traduziu por animi a $^{28}$ ) consiste exatamente em deter na memória uma contínua lembrança (recordação) do que resulta para nós (em decorrência de nossas experiências cotidianas) em um universal ${ }^{29}$ (tema da prólêpis, questão que carece de um estudo à parte); porque essa recordação, em vista do restabelecimento mental de uma nova ordem, facilita em nós uma mais serena abordagem relativa às atuais experiências cotidianas e imediatas ${ }^{30}$.

"incompetente e inábil para oficiar axiomas". Sem ela, os axiomas da ciência nascem sem compromisso com a demonstração e a verificação, e ficam à mercê do acaso e da sorte (tanquam casu quodam aut per occasionem), e resultam infrutíferos: não promovem (segundo ele e ao modo como supôs Epicuro) a obra útil da ciência, aquela que atende ao bem estar e ao conforto da vida humana e que ativa a esperança num futuro melhor (BACON, Francis. Novum organum, I, CVI e CVIII; II, X - Fonte: Nuovo Organo - Novum organum. Texto latino a fronte. A cura di Michele Marchetto. Roma: Bompiani, 2002).

26 mê dóxais taûta páschein all' alógô gé tivi parastásei... (Carta a Heródoto, 81)

27 Carta a Pítocles, 96

28 De rerum natura, III, v. 24 - De rerum natura. De la naturaleza. Introducción, traducciós y Notas de Eduard Valentí Fiol. Barcelona: Bosch, 1985.

29 A questão aqui, que caberia ser tratada sob o conceito epicurista da prólêpsis, remonta a Aristóteles, em particular à indução que supôs no livro I da Metafísica. Lá ele diz que os homens, além da memória, dispõem "de arte e de raciocínio (téchnêi kaì logismoîs)", e que são capazes de compartilhar da empiria (empeirías dè metéchei*)". "Neles, a empiria nasce da capacidade de recordar, e das recordações repetidas da mesma coisa surtem o efeito de uma única empiria, e a empiria se parece com a ciência e com a arte (epistêmê kaì téchnê)". Se parece, porque a empiria, rigorosamente, não se confunde nem com arte e nem com ciência; ela é restrita a um saber faze. Porém, "se parece" com a ciência e a arte na medida em que resulta numa experiência única, universal (Metafísica, I, 1, 980b 25-29; 981a 3). * Metéchô designa uma compartilha e diz respeito a uma certa habilidade ou destreza da qual (mesmo sendo particular) não só um indivíduo mas toda uma comunidade de indivíduos toma parte ou tira proveito.

30 Carta a Heródoto, 82 
As evidências sensíveis, com efeito, não mentem, apenas dão testemunho do que podem e do que estão em (humanas) condições de testemunhar, cabendo a nós (em dependência do nível de racionalidade de cada um) ajuizar. É, pois, neste nível, no do exercício do juízo, que se encerra todo o problema da criteriologia de Epicuro. Epicuro, porém, sendo ele um incorrigível realista no que diz respeito à condição humana, põe ou nos fenômenos ou nas evidências, ou seja, no que se apresenta frente ao nosso campo de observação e que nos atiça, que se manifesta à nossa mente (de sujeitos racionais sencientes), e que, por uma força persuasiva que lhe é própria, se reverte (na maioria) em fonte quer de opiniões falsas quer (o mais raro) de opiniões verdadeiras. Bom exemplo para entender essa força persuasiva poderíamos encontrar no lendário medo que os gregos comuns depositaram no canto da pomba-rola; a questão está no seguinte: o suposto mau agouro do canto da pomba-rola não está em seu canto, não nasce nele, de modo que dele não advém para quem ouve nenhum mal. O mau agouro do canto da pomba-rola só advém para quem põe nele o seu temor: temor que lhe nasce na alma, e que (se não tomar uma atitude de discernimento), ali fica encafuado, restando o indivíduo recluso em seus próprios medos.

A maior parte dos homens formula e cultiva mais opiniões falsas (a pseudodoxía) que opiniões verdadeiras; entretanto (eis a questão), a grande dificuldade está, não propriamente em adotar, mas sim em justificar (racionalmente conceber) como verdadeiras opiniões que são falsas. Muitos gastam alguma energia nessa direção; mas posto que a grande maioria pouco se empenha em exercitar a razão (dentre outros motivos por medo do conflito que se instala na mente, e que sempre é oneroso e incomodativo - quebra ordens mentais estabelecidas) prefere sempre resguardar as velhas opiniões e descartar as novas que lhe surte à mente; ademais, a "instrução" racional de que a maioria dispõe é derivada da recorrência aos mitos, universo dentro do qual os homens cotidianos constroem um modo de ser e de portar-se consuetudinário, ou seja, dele recolhem princípios (em geral derivados de suposições falsas <ýpolêpseis pseudeîs $>$ a respeito da natureza e dos deuses) com os quais se orientam e se arreglam (e assim promovem para si próprios, para a mente, mais malefícios que benefícios). Daí também, e em vista disso, que Epicuro, antes de se ocupar com a formulação racional de critérios racionais regulativos da ação moral e do fazer ciência, se ocupa, antes, com a fundamentação das evidências, porque, segundo ele, são elas (mais precisamente as energeías, as forças nelas inerentes) que estão na base tanto do crer, quanto do fazer ou agir humano.

Além disso, não tendo a doutrina de Epicuro como propósito fundar princípios ou um conjunto de regras racionais, mas apenas explanar 
racionalmente a realidade ou condição humana (seus limites e suas possibilidades), então aqui fica claro, primeiro, porque a sua canônica não se confundia com uma lógica, ou, como quiseram os latinos, com uma dialética; segundo, que filosofar, para o epicurismo consiste, sim, em descobrir princípios seguros ${ }^{31}$, porém, é necessário acrescentar que tais princípios não podem ser de tal modo rígidos e permanentes a ponto de eliminar, num único princípio, a capacidade ou disposição da mente humana de prover novos princípios. Princípios desse tipo adoecem a alma, tanto quanto o excesso de dúvida! "Como em tempo de peste (escreveu Diógenes de Enoanda), a maioria se torna em comum doente de falsas opiniões sobre as coisas (...), e um pega a doença do outro feito as ovelhas" "32; a maioria (esta é a questão) adota tais opiniões como se elas fossem absolutamente certas ou seguras! Daí porque a questão fundamental do epicurismo não se restringe à dogmática do princípio seguro, mas, digamos, à "dogmática" da disposição da inteligência em se auto-prover de princípios edificantes ou máximas eficazes em vista do bem-estar e da paz duradoura da mente humana. "Eu não estimulo ninguém (escreveu igualmente Diógenes de Enoanda) a anuir rapidamente, e sem exame, perante os que dizem isto é verdadeiro"33.

A verdade, com efeito, (a alêthés) para Epicuro é sinônimo de realidade: não é propriamente o que se esconde (que se mostra para alguns e não para outros), mas o que a todos de algum modo se mostra. Além disso, a verdade também não é algo (um dizer) que se inventa a partir de modelos (em geral, restritos, derivados das crenças, quer filosóficas quer religiosas) previamente instituídos para um determinado fim. A verdade passa sempre pelo exercício racional de quem a acolhe. O fato é que inventamos modelos como pontos de referência ${ }^{34}$, e, por eles, constituímos verdades, sobre as quais apoiamos juízos de realidade ou até um sistema de conceitos (princípios) com os quais

31 Pensamos, aqui, no que diz Jean-François Duvernoy, segundo o qual filosofar "consiste em descobrir princípios seguros. (...). Espantos e arrepios são, para o epicurismo, o campo das almas sem princípios seguros" (DUVERNOY, J.-F.. O Epicurismo e a sua tradição antiga. Trad. de Lucy Magalhães. Rio de Janeiro: Zahar, 1993, p. 90).

32 Diógenes de Enoanda, frag. 3 - La philosophie épicurienne sur pierre. Les fragments de Diogène d'Oenoanda. Introduction, traduction et notes par Alexandre Etienne et Dominic O'Meara. Fribourg-Paris: Ed. Universitaires Fribourg/Ed. du Cerf, 1996.

33 Diógenes de Enoanda, frag. 30

34 A título de ilustração: a rigor, os moradores de Santa Maria não conhecem o todo de Santa Maria, e, sim, uma certa Santa Maria, ou seja, a Santa Maria relativa ao seu ponto de referência: a partir do lugar de onde mora. Daí que, por parte do morador ou transeunte, o conhecer Santa Maria é, por princípio, subjetivo, mas com pontos referenciais objetivos, ou seja, de domínio comum, universal, que caracterizam (em termos de conhecimento objetivo) uma comunidade de intelecção relativa à Santa Maria. É a partir da existência dessa comunidade que se torna possível (entre os moradores, ou entre os transeuntes, ou entre os que dizem conhecer Santa Maria) falar de Santa Maria. 
nos arreglamos e nos orientamos. De modo semelhante, dogmatizamos crenças, e, em vista delas, deixamos, em um só tempo, de ser críticos e de ser lúcidos: cultivamos, de podo passivo, a aphrosýne (a irracionalidade, ou, mais exatamente, o não exercício do pensar). Com efeito, na tarefa de nos autoconhecer, de nos arreglar e de nos qualificar, o que mais importa (o prioritário) não está em acolher (mesmo que criticamente) modelos ou crenças, e sim, em averiguar em nós mesmos o que, por natureza, nos induz a agir deste ou daquele modo, quer dizer: de como, por natureza, somos dotados de certos "modelos". Não é fora, mas dentro de nós, que nos deparamos com o melhor dos guias. No que concerne à nossa relação com o mundo (ou seja, com as evidências, com os fenômenos, com os perceptos, enfim, com o outro frente a nós mesmos), quer queira quer não somos afetados de diversas maneiras, e tudo o que nos afeta se impõe sobre nós ( e dispõe sob certa maneira). Ao entrarmos em contato com algo, necessariamente recebemos impressões dele e somos afetados por ele. Só há, todavia, uma maneira de nos esgueirarmos das afetações: harmonizando-nos (a partir de dentro de nós) com o objeto da afetação.

E aqui está a grande questão que se põe na relação entre impulsão (recepção natural) e assentimento (espontâneo e/ou reflexivo). O primeiro passo, por certo, consiste em nos reconhecer (égnômen) em nossa própria realidade afetativa, visto que em nós as impressões sensitivas se impõem involuntariamente (sem condições de eliminá-las), e, facilmente nos induz a formar opinião à qual (como que natural e precipitadamente) damos assentimento. Tal é a condição pela qual viemos a nos capacitar na lida conosco mesmo, sobretudo saber com o que em nós (e de nós) podemos contar. Tratase, com efeito, de uma tarefa, que, necessariamente, deve excluir o litígio com a nossa própria verdade ou realidade humana. $\mathrm{O}$ fato é que somente através da certificação de nossa natureza, a partir do saber quem somos, que estamos em condições de nos inteirar da justa medida de nós mesmos - condição sine qua non da qualificação e do apaziguamento do humano em seu próprio território. Ocorre que é o conhecimento de nossa natureza, e não de algo externo a ela, que põe à mostra nossas forças em suas dimensões apropriadas. É também esse mesmo conhecimento que nos permite avaliar (valorar em dependência do vigor humano que nos é próprio) a nossa real capacitação quanto a um eficiente exercício do juízo: aquele que de fato nos põe na trilha de nossa verdade humana, e que, enfim, viabiliza em nós uma vivência tranquila. 


\section{Kanôn, hêdonê, phrónêsis e agathós}

No que diz respeito ao termo kanôn, ele comparece apenas uma vez nos escritos remanescentes de Epicuro, na Carta a Meneceu. Epicuro faz uso dele vinculando-o às impulsões em vista do prazer; eis a referência: "nós dizemos que o prazer é o princípio e o fim da vida feliz. É ele que antes de tudo aprendemos a reconhecer como um bem primeiro e congenital; depois, é por causa e em vista dele que orientamos as nossas escolhas e as nossas recusas, a ponto de fazermos das sensações de prazer cânones para o ajuizamento de tudo o que é bom"35.

Várias coisas Epicuro pôs em destaque nesse seu dizer: a) que o prazer é o princípio e o fim (archê kaì télos) da vida feliz - o que, aliás, não poderia mesmo ser diferente, uma vez que a vida feliz vem sempre associada à satisfação e ao prazer. [O prazer é princípio porque a felicidade só se põe quando se dá o prazer; e é o fim, porque assim que termina o prazer acaba a felicidade - sem que se possa inferir que da cessação do prazer segue-se a infelicidade $\left.{ }^{36^{*}}\right]$; b) que o prazer é o primeiro dos bens, que, por natureza, aprendemos por experiência a reconhecer, não, todavia, de modo imaginativo ou mediante raciocínio, mas de modo real (mediante experiência); c) que nós logo o reconhecemos porque se trata de um bem nascido conosco, conatural, gerado em nós por natureza, e que em nós (em nossa primeira experiência prazerosa) se manifesta espontaneamente; d) que, por natureza (quer dizer, antes de qualquer instrução) não nos é dado um bem racionalmente concebido ${ }^{37}$, prova disso é que na infância não estamos em condições de concluir pela idéia de bem ou então de derivá-lo por puro raciocínio; e) que é o prazer (mais precisamente as impulsões em vista do prazer) que ativa em nós a busca pelo que, natural e espontaneamente, supomos como sendo bom; f) enfim, que as impulsões de prazer nos acompanha sempre (a par delas o seu oposto, o desprazer), e que são elas que despertam em nós o exercício do juízo: o movimento do acolher e do rejeitar.

A partir do que disse Epicuro, poderíamos formular nestes termos a questão: assim que (na infância) experimentamos o prazer, esse experimentar

35 Carta a Meneceu, 129 - nos valemos também da Carta sobre a Felicidade, A Meneceu. Texto bilíngüe. Tradução de Álvaro Lorencini e Enzo del Carratore. São Paulo: Unesp, 1997.

36 *Alguém poderia perguntar: mas não dá para ser feliz na desgraça? Depende o que se entende por desgraça. Se por desgraça entendemos o externo que nos rodeia ou aflige, então, sim, podemos ser felizes, por exemplo, vivendo em extrema pobreza, em ambiente inóspito, etc; se por desgraça entendemos uma aflixão interna, então, não, porque se trata de sentimentos contraditórios.

37 Spinoza dirá algo semelhante: "Ninguém, por natureza, sabe que deve obediência a Deus, e também não podemos concluir por um qualquer raciocínio..." (SPINOZA, Baruch. Tratado teológico-político. Trad. de Diogo Aurélio: Lisboa: Imprensa Nacional, 1988, p.318). 
como que dispara em nós um móvel, feito uma força <energeía $>$ natural, que nos ativa a buscá-lo sempre ou novamente. Por esse buscar, somos levados ou ao descontrole (a sempre procurá-lo mais e mais) ou à moderação (a nos conter). É a continência ou o desejo por moderação (dado em nós em decorrência de razões naturais, por exemplo, evitar a dor, o desconforto, o mal-estar), que nos estimula a fazer uso do discernimento, da faculdade mediante a qual nos tornamos aptos a prover em nós a medida justa. [Cabe destacar que a nossa natureza, segundo Epicuro, não nos pede por moderação em vista de algum soberano divino que nos recompense, mas apenas em vista de nós mesmos...].

A experiência do prazer desperta em nós umas quantas coisas: a) a experiência de si; b) a disposição da escolha, a perseguir o que dá prazer e a rejeitar o seu oposto, com o que em nós se dá tanto a necessidade de discernir quanto a de exercitar o juízo; c) o reconhecimento de um princípio de bondade, suposto nestes termos: a experiência do prazer desperta em nós uma energeía, um vigor, que, naturalmente, nos move (nos "tende a"). Trata-se, com efeito, de um movimento interno, de uma disposição concebida por Epicuro sob dois termos: conatural <syngenikón> e inata <sýmphyton> (plantada em nós por natureza), e, como tal, um bem, agathón. Não, todavia, um bem imaginário ou ideativo, mas, real, empiricamente dado, experienciado; enquanto tal, fonte de aprendizado (nos termos de uma katarchómetha), ou seja, no sentido de que o indivíduo, na medida em que experimenta e sente prazer, experimenta e sente a si mesmo e a possibilidade de se renovar. Daí que o prazer, enquanto bem primeiro (agathòn prôton), assim o é por uma única razão: porque é o primeiro dos bens que somos capazes de concreta e naturalmente experimentar, e de reconhecê-lo como um bem.

$\mathrm{O}$ acolher (decorrente da experiência de prazer) e o rejeitar (da experiência de dor) se dão em nós, segundo Epicuro, como uma disposição natural que desvela em nós critérios também naturais. Os juízos de verdadeiro e de falso (de certo e de errado) não derivam, e tampouco afetam os nossos sentidos ou sentimentos naturais, mas os de prazer (de gosto) e os de dor (de desgosto), sim. Tais juízos naturais não têm valor moral ou de ciência (é, por exemplo, o julgamento de prazeroso < $<$ gostoso $>$ que define a forma de preparar certos alimentos, e não o de saudável, que requer um saber apropriado). Nossos sentidos são incapazes de tecer juízos morais, mas disso não se segue que sejamos incapazes de juízos de sensação (por exemplo, de gosto e de desgosto). É, pois, em dependência de tais juízos que fundamos um aprendizado natural relativo ao exercício de juízos racionais. 
Epicuro em nenhum momento nega que a razão humana (a phrónêsi ${ }^{38^{*}}$ ) seja critério da edificação do humano. Se negasse não diria, por exemplo, que a vida feliz requer "raciocínios (logismós) prudentes, que se busque cuidadosamente as causas de todas escolhas e das recusas, que, enfim, se remova as opiniões que perturbam a alma"39. O conceito de bem que ele atribuiu ao prazer (à hêdonê) e à phrónêsis têm conotações distintas. Sobre o prazer, eis o que ele escreveu a Meneceu: "O prazer é o que nós reconhecemos como bem primeiro (agathòn prôton) e conatural" ${ }^{40}$; ainda mais adiante: "a natureza de todo prazer detém um bem <que nós é> familiar (oikeían agathòn)" "41; sobre a phrónêsis disse, entretanto, que ela "é o maior de todos os bens (tò mégiston agathòn)"42. Quer dizer: o prazer é o bem que, por primeiro, reconhecemos (égnômen); a phrónêsis é, em si mesma, o maior dos bens, que, por natureza, detemos e que carecemos de alguma maneira colocá-la em marcha. Espontaneamente, a phrónêsis (a ação do pensar) se põe na medida em que, por natureza, somos levados a escolher o que dá prazer e a rejeitar o seu oposto. A empiria é a fonte inequívoca da promoção espontânea em nós desse movimento.

Só é possível a ciência, segundo Epicuro, mediante certificação na empiria. No dizer de Kant, Epicuro tomou por cânon da ciência a seguinte regra: "rejeitar como vazia racionalização tudo o que não deixa certificar sua realidade objetiva através de exemplos evidentes apresentáveis na experiência"43. E, efetivamente, foi assim que ele em tudo procedeu, inclusive no que concerne à idéia do bem. Há, a esse respeito, velada em Epicuro, uma

38 * Demos aqui à phrónêsis o significado de razão em vista da raiz que a sustenta, phrên, dentre outras coisas concebida sobretudo como inteligência, pensamento, vontade, mais precisamente como uma disposição interna em vista do melhor; disposição que implica um ajuizamento, no sentido de dar e de adotar um parecer, em conformidade a uma direção. Daí o sentido de vontade; porém, decorrente de uma deliberação. Não se trata, pois, de uma vontade solta (plenamente livre), anterior a uma decisão, ou seja, phrónesis não expressa a falculdade da vontade, mas a vontade determinada em vista de um fim. No caso específico de Epicuro, estamos certos de que phrónêsis não convém (como habitualmente se faz) ser prontamente traduzida por prudência ou moderação, e sim, como expressão de um juízo sábio: aquele que comporta racionalidade e utilidade (no sentido de eficiência) condizente ao que se espera de um juízo desse tipo. Preferimos, em geral, traduzir phrónêsis por exercício do pensamento ou por a ação do pensar.

39 Carta a Meneceu, 132

40 Carta a Meneceu, 129

41 Carta a Meneceu, 129

42 Carta a Meneceu, 132

43 KANT, I.. Crítica da Razão Prática, 217 - tradução de Valério Rohden. São Paulo: Martins fontes, 2002, p.195. 
pergunta que é fundamental: o que, por natureza, estamos em condições de reconhecer como um bem? E uma resposta no mesmo tom: assim que pela primeira vez experimentamos algo prazeroso (aprazível) nele imediatamente reconhecemos e o tomamos como um bem (um bem "experienciável"). Aliás, por esse mesmo experimentar (na medida em que reconhecemos o prazer) somos também imediatamente levados a identificar o desprazer (o sofrimento ou dor), e, portanto, a reconhecer o mal.

Dá-se que "todo prazer é um bem (ensina Epicuro), mas nem todo prazer deve ser escolhido; do mesmo modo, todo sofrimento (algêdôn) é um mal, mas nem todo mal deve ser evitado. Inclusive, é certamente preciso medir o proveito e o dano proporcional de um ou de outro, a fim de instruir todo julgamento (kríneiv kathêkei) ${ }^{44}$. Ocorre que, em certas circunstâncias, nos valemos de um bem como se fosse um mal, e, inversamente, de um mal como se fosse um bem" 45 . Entretanto: "Ninguém, vendo o mal, escolhe-o por ele mesmo, a não ser que tende a ele como se fosse um bem..." ${ }^{46}$.

É pelo contraposto entre prazer e dor (sofrimento ou desgosto) que as determinações de nossa natureza se encarregam de nos propor, a par do exercício do juízo (no sentido da krísis), o exercício do pensar (da phrónêsis) e a disposição a ser justo (no sentido da dikaíôs $=$ da busca pelo equilíbrio equitativo, nesse caso, não tanto relativo ao sujeito apetente, mas em relação aos outros). É pela experiência do prazer (do que Epicuro chama de hêdonê) que reconhecemos o agathós, o bem. Daí a questão: ao experimentar o prazer, por natureza nos damos conta de um modo valioso de ser, qual seja, experimentamos o bem-estar (aqui, claro, sem uma estrita conotação do que é moralmente bom, mas apenas bom), reconhecido mediante um estado de satisfação física dada em nós como um bem, e uma vez reconhecido tal estado como bom, tendemos (por determinações inerentes à nossa natureza) a buscá-lo, a reproduzi-lo novamente. Não há nesse tender nenhum mal; é a nossa natureza que nos impulsiona, e, por esse impulsionar, nos leva a eleger o prazer como critério, a dar-lhe (ou melhor, reconhecer) uma função: como guia regulativo de nossas escolhas, das que convém acolher e das que é forçoso rejeitar. Saber o que é o prazer todos nós sabemos mais ou menos o

44 "Mesmo sustentando que todo prazer é um bem e toda dor um mal, <os epicureus > não dizem que sempre é necessário escolher o prazer e fugir do mal, mas que devemos medir a partir da quantidade e não da qualidade" (ARÍSTOCLES. citado por EUSÉBIO, Preparação evangélica, XIV, 21, 3; USENER, 442 - a partir de BAILEY, Cyril. The Extant Remains. With short apparatus, translation and notes by C. Bailey. Hildesheim/Zürich/New York: Gerg Olms Verlag, 1989).

45 Carta a Meneceu, 129-130

46 Sentenças vaticanas, 16 
que é; agora, dar-lhe, ou, sobretudo, reconhecer a sua real função natural - eis a grande questão.

Aqui, primeiro, é preciso observar que o tender ao prazer só vem a ser um mal na medida em que, antes de um prazer, produza (sob vários aspectos relativos ao bem-estar humano) desgosto ou dor. A idéia do prazer em Epicuro é sempre edificante, de modo que não comporta qualquer sentido destrutivo (se o prazer vem a ser destrutivo deixa de ser prazer e também de cumprir as suas funções naturais); segundo, e mais uma vez aqui se põe o confronto entre hêdonê (a idéia e a busca pelo prazer) e a phrónêsis (a ação do pensar). A questão é a seguinte: se é pela hêdonê (pelo prazer) que a natureza nos leva a reconhecer o bem, é então pela phrónêsis (pela ação do pensar) que a natureza nos leva a preservar em nós o maior dos bens. A phrónêsis, pois, é esse bem, e nós mais e mais o alcançamos (detemos) na medida em que o exercitamos; a phrónêsis, aliás, é um bem tão grandioso e extraordinário, que Epicuro viu nele (e não na hêdonê) "o ponto de partida mais precioso" da Filosofia ${ }^{47}$.

A phrónêsis (a ação do pensar) é ponto de partida da Filosofia porque ela detém (como sua característica fundamental) exatamente a busca por moderação. A phrónêsis (o exercício do pensar) desperta em nós o seguinte movimento: o pensar busca por equilíbrio (por moderação), a moderação por justiça, a justiça por sabedoria, e a sabedoria pelo aghathós, ou seja, pelo bem, ou, mais precisamente, por uma situação ou estado de bem-estar, sob os seus mais diversos aspectos: físico (corporal), anímico (espiritual), ético (comportamental) e político (comunitário). Daí que o termo kanôn em Epicuro não vem referido prioritariamente ao pensar, e sim, ao ser, sob todos aqueles aspectos e dimensões (que obviamente não se restringe a ser racional). Por kanôn, além disso, Epicuro não indica a rigor um critério (universal) filosófico de juízo, mas, antes, tanto um modo natural (universal) de ser - nos termos de uma qualidade prevalente, manifesta como uma força ou vigor próprio do feitio humano, quanto de portar-se humanamente - "sem violentar a natureza"48.

Kanôn, pois, atende bem mais à forma (relativa ao ser e ao fazer humanos) que ao conteúdo: a) por um lado, é expressão não propriamente de um conjunto de regras a ser seguido ou praticado, mas sim de uma regra segundo a qual é a natureza (e aqui se leva em conta a investigação de suas possibilidade e de seus limites) que deve inspirar os modos de ser e de viver humanos - uma tarefa coletiva, não meramente subjetiva, ou seja, apenas de um indivíduo,

47 Carta a Meneceu, 132. Ler isso em Epicuro e depois aplicar-lhe o refrão de "sensista-sensualista" é evidente que não faz sentido, soa engraçado!

48 Sentenças vaticanas, 21 
grupo ou vertente doutrinária. [Sob esse aspecto, aqui sobressaem duas coisas: uma, a possibilidade de se poder defender Epicuro contra Cícero, ou melhor, contra os estóicos e os dialéticos, que criticavam a doutrina dos epicureus por falta de determinação teórica, ou seja, por carecer de explicitação da essência, do que é (do quid sit) das coisas ${ }^{49}$; outra, mais uma vez se põe evidente o caráter propedêutico da doutrina de Epicuro: ela é propedêutica porque diz respeito a uma tarefa coletiva e não estritamente particular]; b) por outro, kanôn, na medida em que atende mais à forma que ao conteúdo, indica também a necessidade de um critério (igualmente natural) que nos fornece a justa medida quer dos limites e as possibilidades da fruição de prazer, quer de nós mesmos (da autárkeia) e de nossa capacidade de construir uma relação efetivamente humana com o que podemos ser, fazer, e com tudo o que nos cerca.

A título de conclusão: kanôn, em Epicuro, não comporta o habitual sentido (filosófico) de conjunto de normas racionalmente instituído pelo pensar lógico, a não ser o de norma geral de que é passível inferir regras particulares. Sob esse aspecto, kanôn não diz respeito a um catálogo, mas a um modelo ou padrão, enquanto norma, que serve de orientação do agir e de base para o pensar. Trata-se, com efeito, de um modelo endereçado ao epicurista, mas aplicável a todos os homens, aos quais é igualmente requerida a tarefa de se auto-conhecer, e de, por esse conhecer, se auto-determinar. Epicuro a bem da verdade se refere a um reconhecimento do indivíduo enquanto natureza, da qual cabe retirar os "ditames" do devido e do não-devido, de tal modo que a natureza vem a ser o kanôn (a norma ou modelo). Ela é o kanôn por algumas razões: a) porque ela é o objeto tanto do exercício do pensar quanto da instrução da ação (noutros termos: é a fonte das qualidades ou valores existenciais quer da edificação do ser quer dos modos humanos de portar-se); b) porque ela é o de onde a comunidade humana em geral e o filósofo (epicurista) em particular editam o seu êthos, quer relativo aos requisitos do ser, quer do pensar, quer do agir (em outras palavras: ela é a norma, nos termos de uma lei fundamental, orientadora da feitura das demais regras particulares quer atinentes à função humana de ser quer ao ofício filosófico de pensar). 
A criteriologia de Epicuro, portanto, contém um cânon primordial: o voltar-se humano sobre si mesmo em busca de sua própria natureza (de sua identidade) humana. Somam-se a esse cânon a hêdonê (o prazer) e a phrónêsis (o pensar) em razão da função específica que exercem: o da descoberta de si. A hêdonê (o prazer) é o contraposto da dor, porque a dor cinde e o prazer harmoniza, a dor é retrativa, o prazer expansivo, etc.. A retração da dor põe o indivíduo (encaverna-o) para dentro de si; a expansão do prazer põe o indivíduo em contato com o mundo, e, por esse contato, leva-o a debater-se com o conflito, de tal modo (por esse expandir-se) que nele se ativa a phrónêsis: o exercício do pensar, que implica no do juízo. Sem o apresentar-se da phrónêsis, que requer uma ordem (o pensamento pensa mediante conflito, mas a partir ou em busca de uma ordem), requer também cautela e moderação (as impulsões são dispositivos naturais que nos impõem no conflito)... Eis mais uma vez a dialética que pôs em marcha e sustentou a filosofia do epicurismo: o prazer ativa o conflito, o conflito a escolha, a escolha o discernimento, o discernimento a moderação, e a moderação nos leva ao agathós: à descoberta de um bem valioso $0^{50^{*}}$, útil (em sentido altruísta, ou seja, que preserva o interesse em benefício de si mesmo). O agathós é a expressão maior da autárkeia, ou seja, do cuidado de si, em benefício de si e da comunidade em que o indivíduo está inserido. O agathós concebido por Epicuro também veio a ser uma resposta à principal questão com a qual a ética grega se ocupava: qual o maior bem relativo ao aqui e agora da vida humana e qual o melhor meio de acessá-lo?

50 * Em Epicuro o conceito de bem não tem um sentido religioso. Ele é distinto, por exemplo, do conceito bíblico de bem intimamente associado à bondade de Deus. Dado que o Deus bíblico é um Deus pessoal, o conceito de bem também resulta em um bem pessoal. Nesse ponto (na idéia de um bem pessoal, não impessoal), epicurismo e cristianismo coincidem, porém, sob concepções distintas... No que concerne a Epicuro, o conceito de bem, não sendo impessoal, não é derivado de um empenho lógico-racional no sentido de decifrá-lo, ou seja, de dizer o que é. Todavia, disso não se segue, que, para Epicuro, a idéia do bem não tenha valor universal. Ela tem, visto que também o conceito de natureza tem um sentido universal, mas inerente à subjetividade do sujeito natural senciente, que percebe a si mesmo de uma maneira estritamente pessoal. Essa dificuldade de Epicuro em admitir uma irrestrita universalidade ao conceito de bem deriva de Sócrates, para o qual a idéia do bem resultou, em última instância, indecifrável. Cf. Os Caminhos de Epicuro. São Paulo: Loyola, 2009. 